\title{
44. K-Ar DATING RESULTS FROM WHOLE-ROCK AND MINERAL SEPARATES OF THE IZU-BONIN FOREARC BASEMENT, LEG 126 ${ }^{1}$
}

\author{
Rex N. Taylor ${ }^{2}$ and John G. Mitchell ${ }^{3}$
}

\begin{abstract}
Results of conventional K-Ar dating on five samples from two sites from the Izu-Bonin forearc are presented. Two samples recovered from a volcanic edifice and overlying sediments drilled on the western side of the forearc basin (Site 792) indicate a basement age of $34 \mathrm{Ma}$. This is consistent with early Oligocene biostratigraphic ages from the overlying sediments. Three samples from the basement of Hole 793B at the center of the basin are not analytically distinguishable, with a best age of $27.1 \pm 0.6 \mathrm{Ma}$. This is slightly younger than the 30-33 Ma biostratigraphic and magnetostratigraphic estimates from the overlying sediments, suggesting that alteration processes have lowered the apparent $\mathrm{K}$-Ar ages. These ages suggest that syn-rift volcanism occurred in a forearc location during the middle Oligocene.
\end{abstract}

\section{INTRODUCTION AND GEOLOGICAL BACKGROUND}

The Izu-Bonin forearc region, located on the eastern edge of the Philippine Sea, was the target for Ocean Drilling Program (ODP) Leg 126. Two holes reached volcanic basement in the forearc basin (Fig. 1). Hole 792E was located on a frontal-arc high on the western side of the basin (Fig. 1) and reached basement at $80 \mathrm{~m}$ below seafloor ( $\mathrm{mbsf}$ ). This basement high is one of a series of promontories revealed on multichannel seismic profiles (Taylor et al., 1990). Their spacing $(60-100 \mathrm{~km})$ and distribution (linear) suggests that they represent an old arc-volcano chain. These basement highs were recognized by Honza and Tamaki (1985), who named them the Shinkurose Ridge. The basement at Site 792 comprised massive flows of porphyritic two-pyroxene andesite, with the geochemical and petrographic hallmarks of typical calc-alkaline volcanism (Taylor et al., this volume).

At Site 793, drilling penetrated $1404 \mathrm{~m}$ of sediment in the center of the basin before entering volcanic basement. Volcanic breccias intercalated with pillowed and massive flows formed the bulk of the basement sequence. These lavas are petrographically distinct from Hole 792E volcanics, most noticeably as pyroxene crystallizes before plagioclase and phenocrystal magnetite is absent. Geochemically, the Hole 793B basement is similar to boninites in having high-Mg values combined with high-Si and low-Ti concentrations (Taylor et al., this volume).

\section{SAMPLE PREPARATION AND ANALYSIS}

Most horizons within basement contained fresh phenocrysts of clino- and orthopyroxene set in a groundmass of plagioclase and smectitized glass. The pyroxenes were separated by crushing the rock to an $\approx 1 \mathrm{~mm}$ size gravel in an agate bowl and washed with distilled water. Fresh crystals were picked from the crushed rock by hand under an optical microscope. The crystal separates were then repeatedly washed in distilled water in an ultrasonic bath, before a single wash with acetone. Whole-rock samples were crushed to 18-mesh in an agate bowl to a gravel consistence before ultrasonic cleansing in distilled water. Core 126-792E-69R contained abundant fresh amphibole grains in a smectitized vitric sandstone. These grains were separated from their host and treated as for the pyroxene separates.

\footnotetext{
'Taylor, B., Fujioka, K., et al., 1992. Proc. ODP, Sci. Results, 126: College Station, TX (Ocean Drilling Program).

${ }^{2}$ Department of Geology, The University of Southampton, Southampton SO9 5NH, United Kingdom.

${ }^{3}$ Department of Physics, The University, Newcastle upon Tyne NE1 7RU, United Kingdom.
}

Conventional potassium-argon ages were determined for the mineral separates and whole-rock samples as follows. Potassium was determined in triplicate by flame photometry using a Corning EEL 450 instrument with $\mathrm{Li}$ internal standard. Argon was extracted from $\approx 250$-mg aliquots of the samples by fusing them in an furnace followed by gas purification using $\mathrm{Ti}$ sponge and $\mathrm{Al}-\mathrm{Zr}$ alloy getters. The measurement of argon was performed in duplicate on a VG1200C mass spectrometer by isotope dilution using a ${ }^{38} \mathrm{Ar}$ "spike." Interlaboratory calibrations using standard minerals suggest an accuracy of these procedures of better than $2 \%$. Data from these analyses and information on the samples are presented in Table 1.

Unweighted mean values of the potassium and argon contents are presented with the age calculated using the decay constants of Steiger and Jager (1977) with the uncertainty specified by $\pm 1 \sigma$. The atmospheric contamination value is the higher of the values obtained in the duplicate argon analyses.

\section{STRATIGRAPHIC LOCATION OF THE SAMPLES}

Lithostratigraphic, petrographic, and geochemical details of the whole rocks used in this study are given in Taylor et al. (this volume). Analyses of the basement mineralogy are presented in Lapierre et al. (this volume).

\section{Site 792}

Samples dated from Site 792 are lithostratigraphically located in Figure 2. A clinopyroxene separate from the andesite whole-rock sample below had high atmospheric argon and very low potassium contents and produced age errors too large to be meaningfully interpreted. The samples used are listed below.

\section{Amphibole}

A unit of extensively smectitized vitric sandstone was recovered in a $12-m$ interval above the basement contact. This sediment included a 10-cm horizon containing abundant, fresh, brown-green pleochroic amphibole. This horizon is interpreted as an ash layer produced by airfall from a contemporaneous eruption.

\section{Andesite Whole Rock}

The freshest andesite lavas were recovered from the uppermost $15 \mathrm{~m}$ of Hole 792E basement. A 6-cm quarter-core section was taken from the center of a single massive flow and used for whole-rock analysis. 


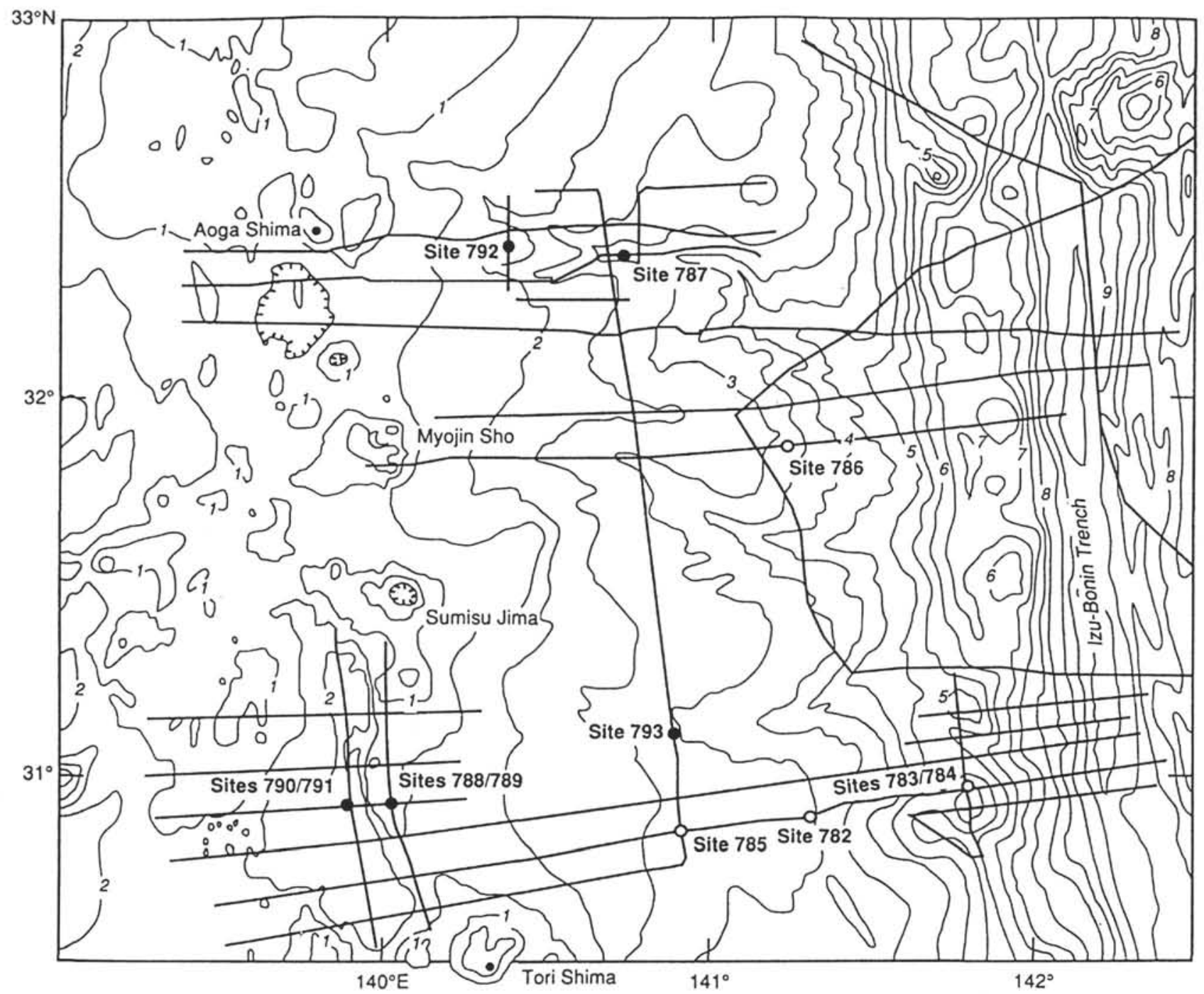

Figure 1. Bathymetric map of the Izu-Bonin arc-trench system between $30.5^{\circ} \mathrm{N}$ and $33^{\circ} \mathrm{N}$. The locations of sites drilled on ODP Legs 125 (open circles) and 126 (solid circles) are shown on the map as are the locations of site survey multichannel seismic lines. Contour interval $=500 \mathrm{~m}$ (numbers on contour lines indicate depth in kilometers). From Taylor, Fujioka, et al. (1990).

Table 1. K-Ar dating results, Holes 792E and 793B.

\begin{tabular}{|c|c|c|c|c|c|}
\hline $\begin{array}{l}\text { Core, section, } \\
\text { interval }(\mathrm{cm})\end{array}$ & $\begin{array}{c}\text { Sample } \\
\text { description }\end{array}$ & $\begin{array}{l}\mathrm{K}_{2} \mathrm{O} \\
(\mathrm{wt} \%)\end{array}$ & $\begin{array}{c}\mathrm{Ar}^{3} \\
\left(\mathrm{~mm}^{3} \mathrm{~g}^{-1}\right)\end{array}$ & $\begin{array}{l}\text { Atmos. } \\
\text { contam. } \\
(\%)\end{array}$ & $\begin{array}{c}\text { Age } \\
(\mathrm{Ma} \pm) \\
(\sigma)\end{array}$ \\
\hline $\begin{array}{c}126-792 \mathrm{E}- \\
69 \mathrm{R}-1 \\
71 \mathrm{R}-3\end{array}$ & $\begin{array}{l}\text { Amphibole } \\
\text { Whole rock }\end{array}$ & $\begin{array}{l}0.056 \pm 0.002 \\
0.240 \pm 0.004\end{array}$ & $\begin{aligned} 6.88 & \pm 0.35 \\
26.00 & \pm 0.8\end{aligned}$ & $\begin{array}{l}91.1 \\
81.1\end{array}$ & $\begin{array}{l}37.7 \pm 2.3 \\
33.3 \pm 1.2\end{array}$ \\
\hline $\begin{array}{c}126-793 \mathrm{~B}- \\
96 \mathrm{R}-1 \\
97 \mathrm{R}-1 \\
112 \mathrm{R}-2\end{array}$ & $\begin{array}{l}\text { Whole rock } \\
\text { Whole rock } \\
\text { Whole rock }\end{array}$ & $\begin{array}{l}0.276 \pm 0.005 \\
0.195 \pm 0.002 \\
0.329 \pm 0.005\end{array}$ & $\begin{array}{l}23.60 \pm 0.09 \\
18.10 \pm 0.06 \\
28.30 \pm 0.09\end{array}$ & $\begin{array}{l}78.0 \\
81.5 \\
76.4\end{array}$ & $\begin{array}{l}26.3 \pm 1.1 \\
28.5 \pm 1.0 \\
26.5 \pm 0.9\end{array}$ \\
\hline
\end{tabular}

Notes: Atmos. contam. $(\%)=$ percentage atmospheric contamination. All data are the mean of two analyses, $\lambda_{c}=0.581 \times 10^{-10} \mathrm{a}^{-1}, \lambda_{\mathrm{B}}=4.962 \times 10^{-10} \mathrm{a}^{-1}$, and ${ }^{40} \mathrm{~K} / \mathrm{K}=1.167 \times 10^{-2}$ atom percent.

\section{Site 793}

Three whole-rock samples were dated from Site 793. Samples of both ortho- and clinopyroxene were found to be too low in potassium to give sufficiently precise, meaningful ages. Whole-rock samples were taken from the basement lavas as shown in Figure 3. The samples used were as follows:
1. clinopyroxene-orthopyroxene phyric basaltic andesite (whole rock) taken from a pillow interior, Unit 4;

2. clinopyroxene-orthopyroxene-plagioclase phyric basaltic andesite (whole rock) sample from the center of a massive flow, Unit 5; and

3. clinopyroxene-orthopyroxene-plagioclase phyric basaltic andesite (whole rock) sample from the center of a massive flow, within Unit 14.

\section{INTERPRETATION OF THE K-AR AGES}

Biostratigraphic ages indicate that the oldest sediments at Site 792 are CP19a $(<30.2 \mathrm{Ma})$, indicating a sediment age of $30 \mathrm{Ma}$ at 765 mbsf (Firth and Isiminger-Kelso, this volume). The whole-rock age of $33.3 \pm 1.2 \mathrm{Ma}$ for a basement andesite can be viewed as a reasonable estimate for the basement lavas during the hydration/alteration of interstitial glass. Amphibole in the sediments directly overlying basement produced an age of $37.7 \pm 2.3 \mathrm{Ma}$. This can be interpreted as a maximum age because of the possibility of trapped preexisting radiogenic argon within the crystals. These results suggest a minimum basement age of $33 \mathrm{Ma}$ (early late Oligocene) and a minor hiatus between basement formation and sedimentation (Fig. 4). 


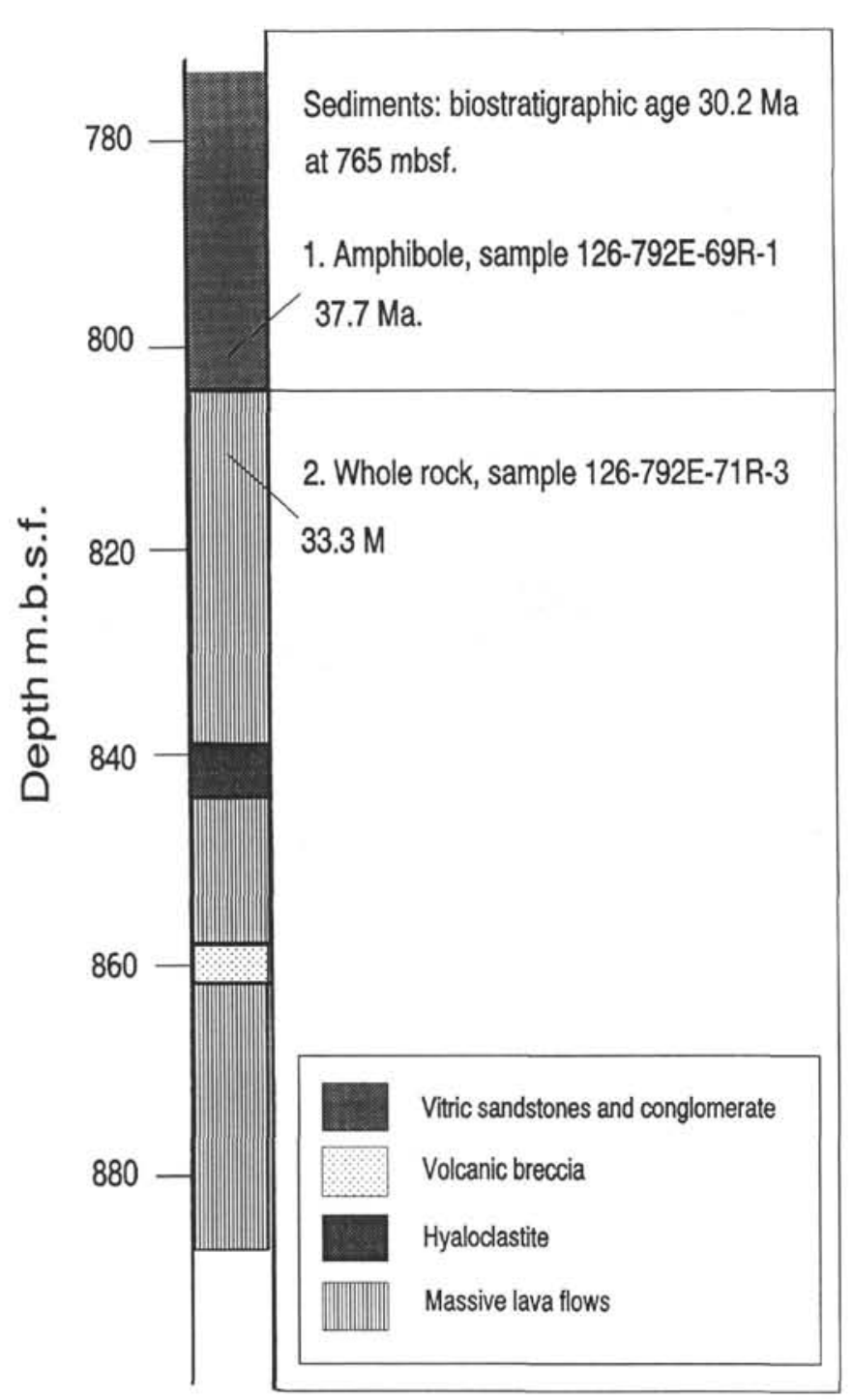

Figure 2. Chronostratigraphic data from Hole 792E. Numbers adjacent to age determinations refer to Table 1 and text.

Sediments overlying Hole 793B basement were biostratigraphically and magnetostratigraphically dated as Chron 10R, 30-33 Ma (Taylor, Fujioka, et al., 1990). Basement K-Ar ages lie in the range from 26 to $28.5 \mathrm{Ma}$. This implies that the whole-rock samples have undergone an alteration event with a concomitant loss of radiogenic argon. A clinopyroxene separate also gives an age of about $26 \mathrm{Ma}$, which suggests that the phenocrysts have also lost argon during alteration. In light of these results, the sediment ages for Site 793 are unquestionably a more reliable minimum age for the basement.

\section{DISCUSSION AND CONCLUSIONS}

Age relations between basement at Sites 792 and 793 provide insights into the temporal development of the Izu-Bonin arc-trench crust. Although the $\mathrm{K}-\mathrm{Ar}$ ages are likely to have been disturbed by posteruptive processes, the data suggest that basement deposits at Sites 792 and 793 are younger than the volcanics of the outer-arc high.

The calc-alkaline volcanic edifice drilled at Site 792 can be defined as part of an early Oligocene volcanic arc. This arc lay to the west of the Eocene outer-arc high and trench (Fig. 4). During the Oligocene, the outer-arc high was separated from the Hole 792E

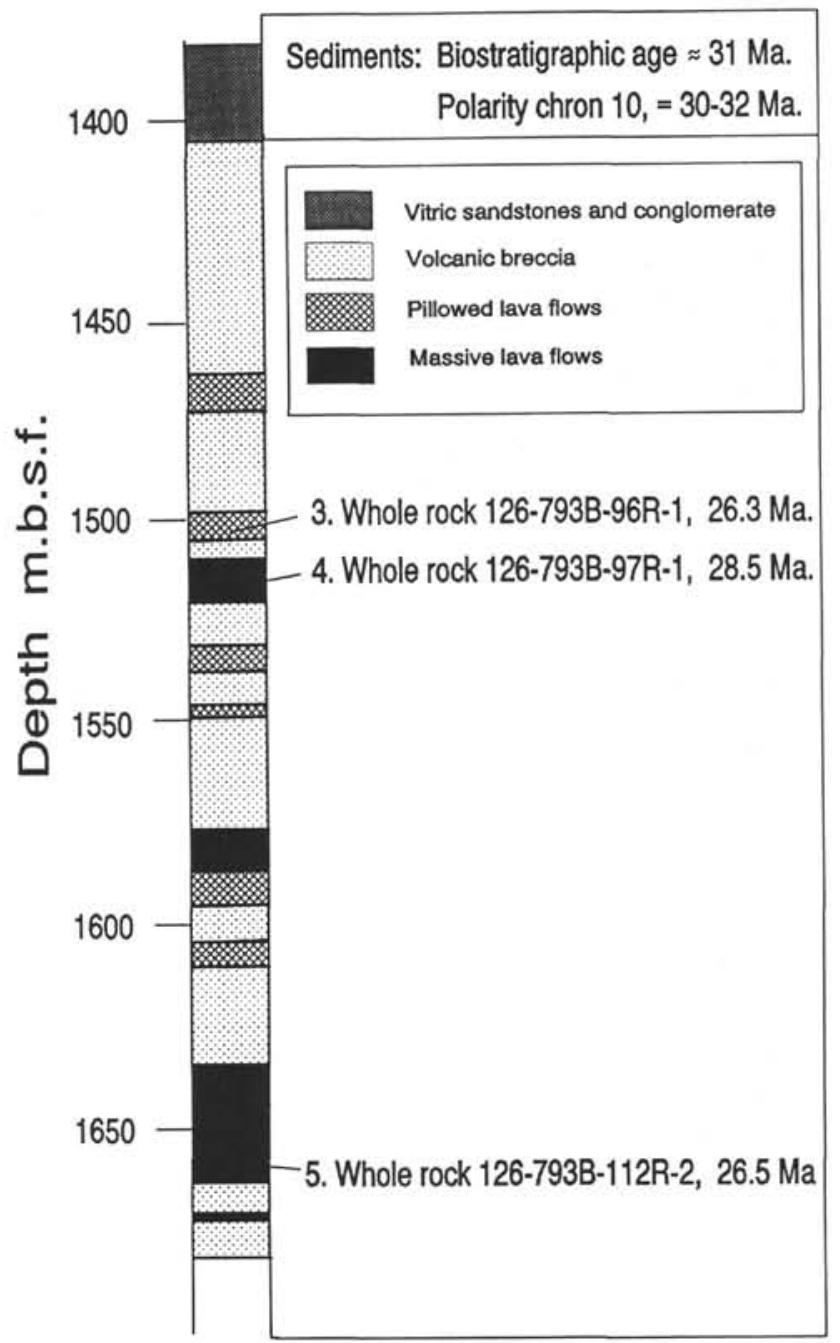

Figure 3. Chronostratigraphic data from Hole 793B. Numbers adjacent to age determinations refer to Table 1 and text.

volcanic arc by rifting. This extension produced a basin on the trench side of the arc and the syn-rift boninitic volcanism found in Hole 793B. As such, Hole 793B basement represents one of the few well-constrained examples of forearc volcanism. Because of the apparently young K-Ar ages for Site 793, it is difficult to constrain the forearc rifting to syn- or post-arc activity. In light of this forearc rifting event, we suggest that the Eocene outer-arc high may have been generated in a similar fashion. In the Eocene, the "arc" unit would be represented by the present Palau-Kyushu Ridge, and rifting would have been instigated in the forearc in the young, pre-existing Philippine Sea crust.

\section{ACKNOWLEDGMENTS}

We would like to thank I. Croudace and J. A. Pearce for advice on sample preparation and to the reviewers for guidance in revision of this manuscript. R. N. Taylor was supported by Natural Environment Research Council Grant No. GST/02/16.

\section{REFERENCES}

Honza, E., and Tamaki, K., 1985. The Bonin Arc. In Nairn, A.E.M., Stehli, F. G., and Uyeda, S. (Eds.), The Sea (Vol. 7): The Ocean Basins and Margins: New York (Plenum), 459-502. 

Frontal-arc
Fore-arc
Outer-arc
Active arc
high
basin
high

W

Hole 792E

Hole 793B

Hole 786B

E
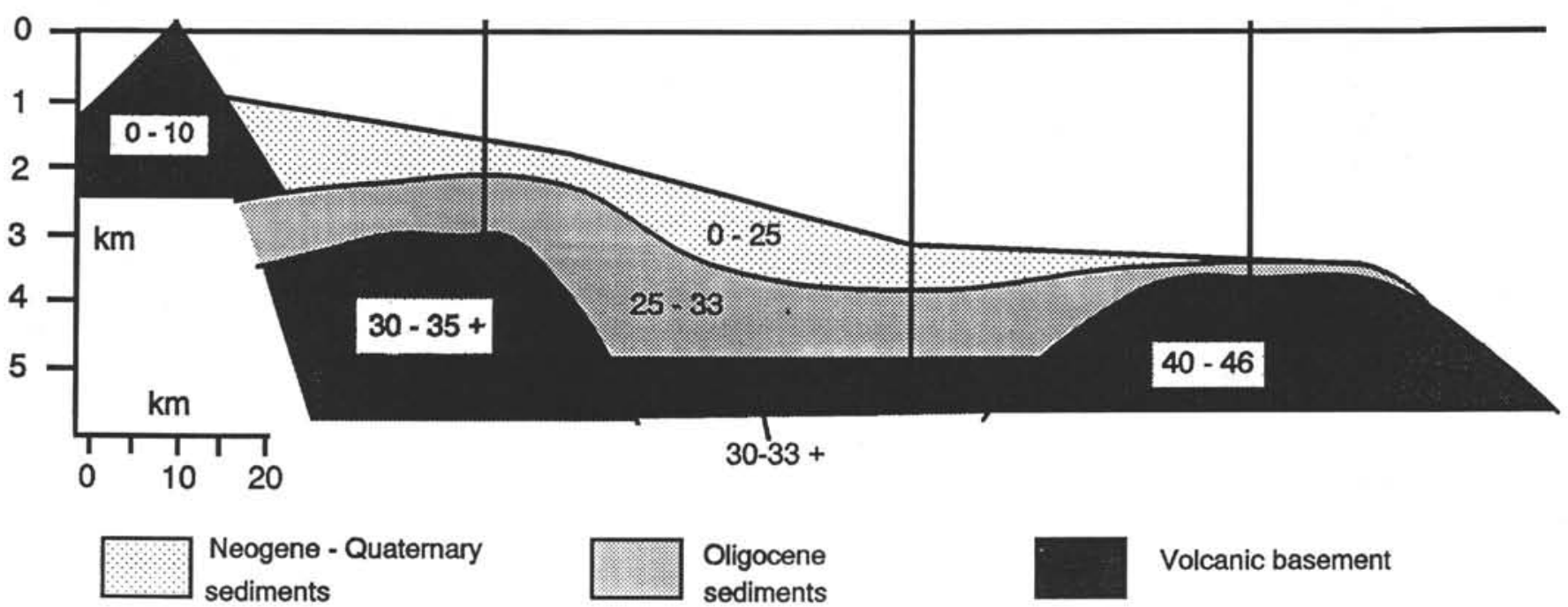

Volcanic basement

Figure 4. Schematic west-east cross section across the Izu-Bonin Arc. Numbers within each unit are age ranges from radiometric determinations (this study; Tsunakawa, 1983) and from Leg 126 drilling results (Taylor, Fujioka, et al., 1990).

Steiger, R. H., and Jäger, E., 1977. Subcommission on geochronology: convention on the use of decay constants in geo- and cosmochronology. Earth Planet. Sci. Lett., 36:359-362.

Taylor, B., Fujioka, K., et al., 1990. Proc. ODP, Init. Repts., 126: College Station, TX (Ocean Drilling Program).

Taylor, B., Moore, G., Klaus, A., Systrom, M., Cooper, P., and MacKay, M., 1990. Multichannel seismic survey of the central Izu-Bonin Arc. In Taylor, B., Fujioka, K., et al., Proc. ODP, Init. Repts., 126: College Station, TX (Ocean Drilling Program), 51-60.
Tsunakawa, H., 1983. K-Ar dating on volcanic rocks in the Bonin Islands and its tectonic implication. Tectonophysics, 95:221-232.

Date of initial receipt: 26 December 1990

Date of acceptance: 6 September 1991

Ms 126B-168 